\title{
Impact of macroalgal blooms and wader predation on intertidal macroinvertebrates: experimental evidence from the Mondego estuary (Portugal)
}

\author{
Ricardo J. Lopes*, Miguel A. Pardal, João C. Marques \\ Institute of Marine Research (IMAR), Department of Zoology, University of Coimbra, 3000 Coimbra, \\ Portugal
}

Received 12 May 1999; received in revised form 4 February 2000; accepted 17 February 2000

\begin{abstract}
The effect of macroalgal blooms and predation by wading on benthic macroinvertebrates was examined in the Mondego estuary, Portugal, during spring 1997. Introduced macroalgal cover and exclusion of predators were used to examine changes in density of macroinvertebrates using univariate and multivariate analyses. There was no evidence of changes in numbers of macroinvertebrates due to predation. Macroalgae were, however, responsible for a decrease in abundance of the worms Amage adspersa (Grube) and Streblospio shrubsolii (Buchanan), and a substantial increase in numbers of Capitella capitata (Fabricius). The density of the worm Hediste diversicolor (O.F. Müller) increased during the first month and decreased after 2 months, associated with macroalgal cover. There were no differences in abundances of macroinvertebrates between different depths. Overall, only polychaete species were affected by macroalgae. Multivariate analysis also showed clear differences in assemblages of macroinvertebrates due to the presence of macroalgae. (C) 2000 Elsevier Science B.V. All rights reserved.
\end{abstract}

Keywords: Macroalgae blooms; Intertidal macroinvertebrates; Wader predation; Mondego estuary

\section{Introduction}

Mass blooms of green macroalgae are common on intertidal flats all over the world (Raffaelli, 1992; Hardy et al., 1993; Hodgkin and Hamilton, 1993; McComb and Davis, 1993; Everett, 1994; Metzmacher and Reise, 1994; Marques et al., 1997; Raffaelli et al., 1998). Most such blooms are caused by combinations of three main factors: combined

*Corresponding author. Tel.: + 351-239-836-386; fax: + 351-239-823-603.

E-mail address: riclopes@ci.uc.pt (R.J. Lopes) 
nitrogen (nitrate and ammonia), phosphorous and changes in the hydrography of the area (e.g., McComb and Humphries, 1992; Reise and Siebert, 1994; Flindt et al., 1997). Other factors can also be limiting, such as temperature, sub-optimal light and grazer conditions (Aubert, 1990; Jeffrey, 1993; Raffaelli et al., 1998). The blooms can have significant effects on the microbiology and chemistry of the underlying sediments (Hull, 1987), on the physical environment at the sediment-water interface (Everett, 1991), on other plants (Flindt et al., 1997), on benthic invertebrates (Hull, 1987; Pardal, 1998; Lillebø et al., 1999) and on other animals that use the resources found in the intertidal flats (Tubbs and Tubbs, 1980).

According to Raffaelli et al. (1998), macroalgal blooms can be responsible for significant reductions in abundance of prey (mainly surface feeders), increases in abundance of prey (mainly epibenthic species) and for forcing deeper-living species such as large bivalves and polychaetes to the sediment surface, increasing their chance of being eaten. The presence of macroalgae can affect predation of invertebrates by waders, by changing density, detectability or accessibility of prey. Density of prey can be reduced or increased depending on the species and conditions (Hull, 1987; Raffaelli et al., 1991; Everett, 1994), while detectability can be reduced by camouflage against the macroalgal mats (Hull, 1987; Everett, 1994). Accessibility may be increased by upward vertical migration of prey (Kalejta and Hockey, 1991). Moreover, the combined presence of macroalgal cover and predation can either attenuate or intensify the effects of each factor on the density of macroinvertebrates (Raffaelli et al., 1998).

The Mondego estuary $\left(40^{\circ} 08^{\prime} \mathrm{N}, 8^{\circ} 50^{\prime} \mathrm{W}\right)$ is an estuarine system on the Portuguese Atlantic coast (Fig. 1), that supports a large number of waders during migration and winter, due to an important intertidal benthic macroinvertebrate community (Marques et al., 1993, 1997; Múrias et al., 1996, 1997; Flindt et al., 1997). The estuary is $7 \mathrm{~km}$ long and $2-3 \mathrm{~km}$ wide and covers an area of $1.072 \mathrm{ha}$. Intertidal flats (227 ha) occur in the south and north arms of the estuary and are the main feeding area for waders during migrations and in winter. The number of waders ranges between 2000 and 2500 throughout the spring migration. The most common species are Dunlin Calidris alpina (L.), Grey plover Pluvialis squatarola (L.), Ringed plover Charadrius hiaticula L. and Kentish plover Charadrius alexandrinus L. (Múrias et al., 1997).

Seasonal intertidal macroalgal blooms (mainly Enteromorpha spp.) have occurred in both arms during the last decade (Marques et al., 1993, 1997; Flindt et al., 1997; Martins et al., 1997; Pardal, 1998; Lillebø et al., 1999), probably due to an increase of nutrients in the estuary, which supports industrial activities and aquaculture and receives nutrients from 15000 ha of cultivated land (mainly rice fields). The annual nitrogen loading to the south arm was estimated roughly as 134 tons (mainly nitrates), of which 14 tons remain in the system (Flindt et al., 1997). The blooms of Enteromorpha spp. (E. compressa (L.), E. intestinalis (L.) and E. ramulosa (Smith)) are usually followed by Ulva sp. and Gracilaria verrucosa (Hudson). These blooms occur mainly in the inner areas of the south arm, from late winter to early summer, when the amount of algae often crashes (Marques et al., 1993, 1997; Flindt et al., 1997; Martins et al., 1997; Lillebø et al., 1999).

Manipulative field experiments are the least equivocal method to study interactions between species or testing hypothesis about cause-effect relationships (Underwood, 


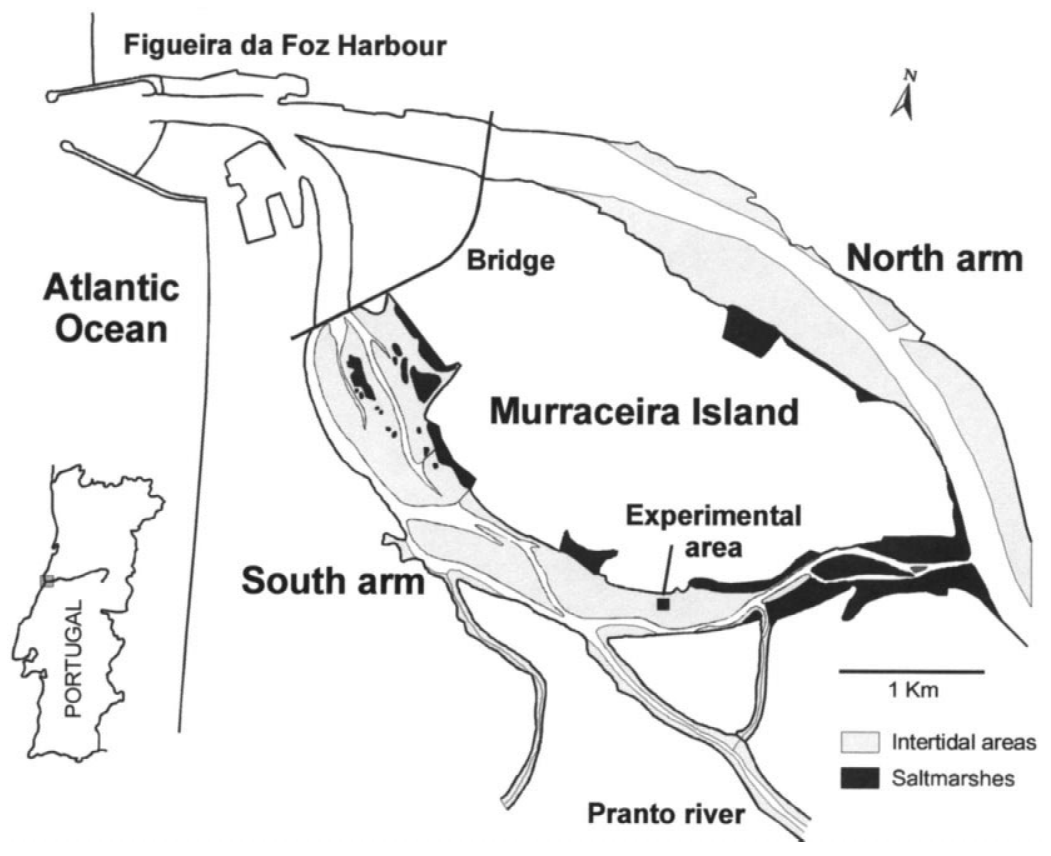

Fig. 1. Mondego estuary with intertidal areas. Localisation of the experimental area.

1981). Experiments in the study of macroalgal blooms have been compared with results from sampling of macroinvertebrates sampling between areas with macroalgae and areas without macroalgae (e.g., Raffaelli et al., 1991). Also, experimental exclosure of waders have sometimes been used to study their effects on invertebrates (Baird et al., 1985; Piersma, 1987; Székely and Bamberger, 1992; Trush et al., 1994). Few such studies have, however, detected significant reductions in macroinvertebrate densities where, theoretically, waders removed a large proportion of benthic production (Baird et al., 1985).

This paper describes an experiment to evaluate the influences of macroalgae and predation on density of macroinvertebrates during spring 1997.

\section{Methods}

The experiment was done during spring 1997 in a 27-ha mudflat (Pranto mudflat), free from algal cover, in the inner part of south arm. At this time of the year, according to previous studies (Marques et al., 1993, 1997; Flindt et al., 1997; Martins et al., 1997; Lillebø et al., 1999), macroalgal biomass can attain more than $450 \mathrm{~g} \mathrm{~m}^{-2}$ (AFDW) and numbers of waders are large due to spring migration (Múrias et al., 1996, 1997). The Pranto mudflat, in the south arm of the Mondego River (Fig. 1) is characterised by fine sediments and is the main feeding area for waders during spring (Múrias et al., 1996). 


\subsection{Experimental design}

To separate the effects of macroalgal cover and wader predation, four treatments were used: NA, open areas with no algal cover; A, open areas with algal cover added artificially; NAE, areas with no algal cover, plus wader exclosures; AE, areas with added macroalgae cover, plus wader exclosures.

Each treatment was replicated five times and the plots consisted of $2 \mathrm{~m}$ side squares. Each plot NA and A was delimited with four bamboo canes only. All plots were located at the same tidal height in a silted area, with no algal cover and an average period of emersion of $8 \mathrm{~h}$ per tidal cycle. The replicates of treatments were interspersed in a rectangular $4 \times 5$ matrix, with the plots $10 \mathrm{~m}$ apart from each other (Hurlbert, 1984; Raffaelli and Hawkins, 1996; Underwood, 1997). Birds were excluded from the plots NAE and AE using three plastic strings running horizontally round four wooden corner posts. A nylon mesh (1-cm mesh size) was used as roof at $0.5 \mathrm{~m}$ above the sediment surface.

\subsubsection{Effect of exclosures}

The effect of the exclosures themselves on densities of invertebrates was not monitored during the experiment. The design probably minimised the potential effects of this kind of structures, for several reasons: (a) large areas $\left(4 \mathrm{~m}^{2}\right)$ were used to minimise edge effects; (b) only an inner area $\left(1 \mathrm{~m}^{2}\right)$ inside each plot was sampled to minimise possible edge effects; (c) the experiment was in an area with weak currents, which minimised turbulence; (d) the roof net was submerged only during spring tides, also minimising turbulence; and (e) use of a minimum of material to prevent wader predation, as in several other studies where no evidence of alterations in granulometry occurred (Rafaelli and Milne, 1987; Trush et al., 1994; Sewell, 1996).

\subsubsection{Artificial macroalgae cover}

On March 24, plots with algae (A and AE) were covered with green algae (Enteromorpha sp.) taken from adjacent areas (Hull, 1987; Raffaelli et al., 1991; Metzmacher and Reise, 1994). In each plot, $3 \mathrm{~kg}$ wet weight (WW) were placed, corresponding to the average value during March in eutrophicated areas, in order to simulate the natural conditions (Flindt et al., 1997; Lillebø et al., 1999). Although the amount of algae added was less than in other experiments, this approach is valid because the algal biomass used was similar to that in the adjacent areas and increased during the experiment, as expected. The amount of algae in each plot was determined in situ with a balance. Every piece of algae was washed and rinsed with water to remove as many macroinvertebrates as possible, to minimise translocation of organisms. Only pieces of algae which were attached to shells were used, allowing the algae to be fixed to the substrata, by burying the shells. This minimised removal of algae by the tide.

\subsection{Effectiveness and maintenance of plots}

Every 5-7 days, the plots were inspected for bird footprints and droppings to assess the success of the exclosures and the use of the area (Rafaelli and Milne, 1987; Everett, 
1994; Trush et al., 1994). Artefacts and algae on plots NA and NAE were removed. Red algae (mainly Gracilaria spp.) also settled in the plots during the experiment but because this is a common process, these algae were not removed. The weekly inspection allowed us to verify that around all plots and inside plots NA and A, wader footprints and droppings (mainly Calidris alpina, Pluvialis squatarola and Numenius phaeopus (L.)) were present throughout the experiment, with the same frequency as adjacent areas. However, we do not know if the presence of the bamboo canes $(15 \mathrm{~cm}$ height $)$ affected the food intake by waders in plots NA and A. Inside plots NAE and AE, no signs of waders were detected.

\subsection{Sampling}

The experiment lasted for 2 months and the plots were sampled on two occasions (April 28 and May 26). At each time, five $20 \mathrm{~cm}$ deep core samples (5.6 cm diameter) were taken randomly in the inner part of each plot $(50 \mathrm{~cm}$ from the edge). The cores were $20 \mathrm{~cm}$ deep, because this was assumed to be the maximal depth at which most of the macroinvertebrates lay. Each core was divided at $5 \mathrm{~cm}$ depth because this was assumed to be the maximal harvestable depth for the waders present (Cramp and Simmons, 1983; Kalejta, 1993). Samples were rinsed through a $500 \mu \mathrm{m}$ sieve and preserved in $4 \%$ buffered formalin for later identification.

\section{Results}

\subsection{Algae}

In April, the total algal biomass in $\mathrm{A}$ and $\mathrm{AE}$ plots was $121.6 \mathrm{DW} \mathrm{g} \cdot \mathrm{m}^{-2} \pm 11.9$ (S.E.M.) and there was a slight increase in May $\left(158.5 \mathrm{DW} \mathrm{g} \cdot \mathrm{m}^{-2} \pm 13.5\right)$ but, within each month, there were no significant differences in the total algae biomasses between $\mathrm{A}$ and AE plots. The separate analysis of green and red macroalgae revealed that, in April, no significant differences occurred between treatments, while in May, there was a significant difference in green algae biomass between algae treatments $(U=2, P=$ 0,032). This was compensated by the red algae, whose biomasses were not significantly different between algae treatments. Total algae biomass in NA and NAE plots was always vestigial.

\subsection{Macrofaunal densities}

Only the seven most abundant species of prey were analysed. The gastropod Hydrobia ulvae was by far the most abundant species, followed by the polychaetes Amage adspersa and Streblospio shrubsolii.

\subsubsection{Univariate analysis}

Algae caused a significant increase in density of Capitella capitata and in densities of Amage adspersa and Streblospio shrubsolii. There was a significant algae $\times$ predation 
Table 1

Analyses of variance of the densities of invertebrates $\left[\log _{10}(x+1) \text { transformation; variances homogeneous after transformation, Cochran's tests } P>0.05\right]^{\mathrm{a}}$

\begin{tabular}{|c|c|c|c|c|c|c|c|c|c|c|c|c|c|c|c|c|c|}
\hline \multirow[t]{2}{*}{ Source } & df & MS & $F$ & $P$ & & MS & $F$ & $P$ & & MS & $F$ & $P$ & & MS & $F$ & $P$ & \\
\hline & \multicolumn{4}{|c|}{ Hydrobia ulvae } & \multicolumn{4}{|c|}{ Scrobicularia plana } & \multicolumn{4}{|c|}{ Hediste diversicolor } & \multicolumn{4}{|c|}{ Amage adspersa } & \\
\hline A & 1 & 0.04 & 0.28 & 0.60 & $n s^{b}$ & 3.12 & 2.07 & 0.15 & $\mathrm{~ns}^{\mathrm{b}}$ & 0.08 & 0.03 & 0.86 & ns & 21.01 & 10.43 & 0.005 & $* *$ \\
\hline $\mathrm{P}$ & 1 & 0.02 & 0.14 & 0.71 & $n s^{\mathrm{b}}$ & 1.52 & 1.01 & 0.32 & $\mathrm{~ns}^{\mathrm{b}}$ & 0.23 & 0.10 & 0.76 & $\mathrm{~ns}$ & 0.23 & 0.12 & 0.74 & ns \\
\hline $\mathrm{T}$ & 1 & 0.40 & 3.56 & 0.08 & ns & 6.17 & 3.58 & 0.08 & ns & 0.25 & 0.41 & 0.53 & $\mathrm{~ns}$ & 20.34 & 13.03 & 0.002 & $* *$ \\
\hline$A \times P$ & 1 & 1.31 & 8.81 & 0.003 & $* *^{\mathrm{b}}$ & 2.38 & 1.58 & 0.21 & $\mathrm{~ns}^{\mathrm{b}}$ & 0.23 & 0.10 & 0.76 & $\mathrm{~ns}$ & 0.13 & 0.07 & 0.80 & ns \\
\hline $\mathrm{A} \times \mathrm{T}$ & 1 & 0.00 & 0.03 & 0.86 & ns & 1.57 & 0.91 & 0.35 & ns & 19.78 & 31.89 & 0.000 & $* * *$ & 3.08 & 1.97 & 0.18 & $\mathrm{~ns}$ \\
\hline $\mathrm{P} \times \mathrm{T}$ & 1 & 0.08 & 0.72 & 0.41 & ns & 1.19 & 0.69 & 0.42 & ns & 0.05 & 0.08 & 0.79 & ns & 3.24 & 2.07 & 0.17 & ns \\
\hline $\mathrm{A} \times \mathrm{P} \times \mathrm{T}$ & 1 & 0.18 & 1.59 & 0.23 & ns & 0.01 & 0.00 & 0.95 & ns & 3.17 & 5.10 & 0.04 & $*$ & 0.51 & 0.33 & 0.58 & ns \\
\hline Plot $(\mathrm{A} \times \mathrm{P})$ & 16 & 0.14 & 0.92 & 0.55 & ns & 0.83 & 0.48 & 0.92 & ns & 2.30 & 1.50 & 0.11 & $\mathrm{~ns}$ & 2.01 & 4.14 & 0.000 & $* * *$ \\
\hline $\mathrm{T} \times$ Plot $(\mathrm{A} \times \mathrm{P})$ & 16 & 0.11 & 0.75 & 0.74 & ns & 1.72 & 1.09 & 0.37 & $\mathrm{~ns}$ & 0.62 & 0.40 & 0.98 & $\mathrm{~ns}$ & 1.56 & 3.21 & 0.000 & $* * *$ \\
\hline \multirow[t]{2}{*}{ Residual } & 160 & 0.15 & & & & 1.58 & & & & 1.54 & & & & 0.49 & & & \\
\hline & & \multicolumn{4}{|c|}{ Streblospio shrubsolii } & \multicolumn{4}{|c|}{ Capitella capitata } & \multicolumn{4}{|c|}{ Oligochaeta sp. } & & & & \\
\hline A & 1 & 25.02 & 22.46 & 0.000 & $* * *$ & 123.58 & 33.89 & 0.000 & $* * *$ & & 7.04 & 2.26 & 0.15 & $\mathrm{~ns}$ & & & \\
\hline$P$ & 1 & 1.98 & 1.78 & 0.20 & ns & 0.26 & 0.07 & 0.79 & ns & & 2.16 & 0.69 & 0.42 & ns & & & \\
\hline $\mathrm{T}$ & 1 & 0.35 & 0.18 & 0.68 & ns & 0.06 & 0.04 & 0.85 & ns & & 0.87 & 0.71 & 0.41 & $\mathrm{~ns}$ & & & \\
\hline$A \times P$ & 1 & 0.10 & 0.09 & 0.77 & $\mathrm{~ns}$ & 21.07 & 5.78 & 0.03 & $*$ & & 0.72 & 0.23 & 0.64 & $\mathrm{~ns}$ & & & \\
\hline $\mathrm{A} \times \mathrm{T}$ & 1 & 0.31 & 0.16 & 0.69 & ns & 0.98 & 0.56 & 0.46 & $\mathrm{~ns}$ & & 1.01 & 0.82 & 0.38 & $\mathrm{~ns}$ & & & \\
\hline $\mathrm{P} \times \mathrm{T}$ & 1 & 0.02 & 0.01 & 0.93 & ns & 0.61 & 0.35 & 0.56 & $\mathrm{~ns}$ & & 0.40 & 0.32 & 0.58 & ns & & & \\
\hline $\mathrm{A} \times \mathrm{P} \times \mathrm{T}$ & 1 & 0.15 & 0.08 & 0.78 & $\mathrm{~ns}$ & 0.10 & 0.05 & 0.82 & $\mathrm{~ns}$ & & 0.00 & 0.00 & 1.00 & $\mathrm{~ns}$ & & & \\
\hline Plot $(\mathrm{A} \times \mathrm{P})$ & 16 & 1.11 & 1.99 & 0.02 & $*$ & 3.65 & 2.40 & 0.003 & $* *$ & & 3.12 & 2.23 & 0.006 & $* *$ & & & \\
\hline $\mathrm{T} \times \operatorname{Plot}(\mathrm{A} \times \mathrm{P})$ & 16 & 1.92 & 3.41 & 0.000 & $* * *$ & 1.74 & 1.15 & 0.32 & ns & & 1.22 & 0.87 & 0.60 & $\mathrm{~ns}$ & & & \\
\hline Residual & 160 & 0.56 & & & & 1.52 & & & & & 1.40 & & & & & & \\
\hline
\end{tabular}

${ }^{\mathrm{a}}$ Factors: $+/-$ algae $(\mathrm{A}) ;+/-$ predation $(\mathrm{P})$; time $(\mathrm{T})$; all fixed factors. Plots are random, nested on $\mathrm{A} \times \mathrm{P}$.

${ }^{\mathrm{b}}$ Residual and plot $(\mathrm{A} \times \mathrm{P})$ MS terms were pooled and the resultant term used as the denominator for the $F$ ratio.

Post-hoc pooling was done at $P>0.25$. *P $<0.05 ; * * P<0.01 ; * * * P<0.001$; ns not significant. 


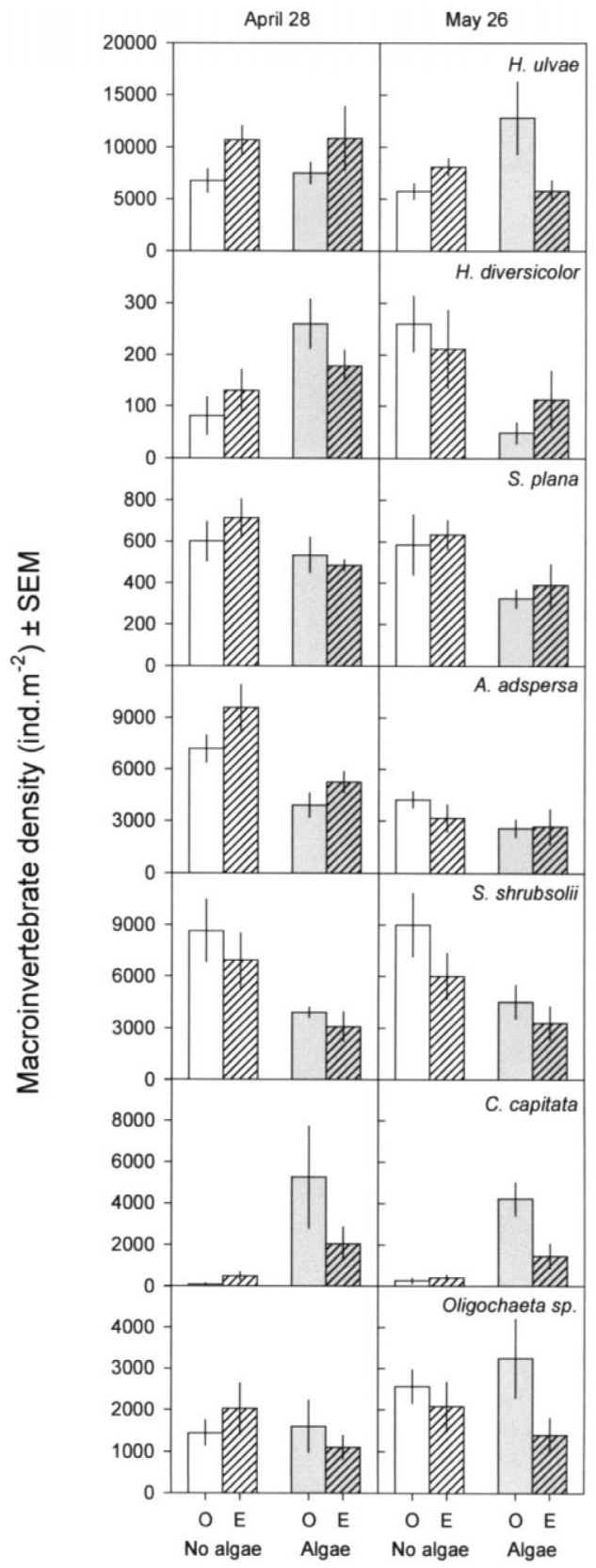

Fig. 2. Total macroinvertebrate density, after 1 (April 28) and 2 months (May 26) after the beginning of the experiment. 
interaction with an higher increase in the density of Capitella capitata associated with the presence of algae when predation occurred. For some of these species, as well as for Oligochaeta sp., there was also a significant variation between plots and between both sampling dates (Table 1 and Fig. 2). The abundance of Hediste diversicolor increased in the first month associated with the presence of algae, but, in the second month, algae had a negative effect. There was a significant Algae $\times$ predation interaction for Hydrobia ulvae, but there was no common trend between months. Neither predation nor algae altered the abundance of species between depths (Table 2 and Fig. 3) and there were no interactions between the factors depth and algae or predation.

\subsubsection{Multivariate analysis}

Significant differences due to the presence of macroalgae were detected by ANOSIM for April $28(R=0.542 ; P=0.001)$ and May $25(R=0.426 ; 0.002)$. Predation was not significant in either month - April $28(R=0.01 ; P=0.431)$ and May $25(R=0.028$; $P=0.341)$. Two-dimension ordination plots (nMDS) showed a gradient of distinction

Table 2

Analyses of variance of the densities of invertebrates at two depths $\left[\log _{10}(x+1)\right.$ transformation; variances homogeneous after transformation, Cochran's tests $P>0.05]^{\mathrm{a}}$

\begin{tabular}{|c|c|c|c|c|c|c|c|c|c|c|c|c|c|}
\hline \multirow[b]{2}{*}{ Source } & \multirow[t]{2}{*}{ df } & \multicolumn{3}{|c|}{ Hydrobia ulvae } & & \multicolumn{3}{|c|}{ Scrobicularia plana } & & \multicolumn{3}{|c|}{ Hediste diversicolor } & \\
\hline & & MS & $F$ & $P$ & & MS & $F$ & $P$ & & MS & $F$ & $P$ & \\
\hline A & 1 & 0.15 & 0.19 & 0.67 & ns & 0.04 & 0.04 & 0.85 & ns & 6.26 & 3.56 & 0.08 & ns \\
\hline$P$ & 1 & 0.41 & 0.51 & 0.48 & $\mathrm{~ns}$ & 0.03 & 0.02 & 0.88 & ns & 0.57 & 0.33 & 0.58 & ns \\
\hline $\mathrm{T}$ & 1 & 0.07 & 0.14 & 0.71 & ns & 1.06 & 1.52 & 0.24 & ns & 1.19 & 0.46 & 0.51 & ns \\
\hline $\mathrm{D}$ & 1 & 15.29 & 11.82 & 0.003 & $* *$ & 1.16 & 0.94 & 0.35 & ns & 0.85 & 0.56 & 0.46 & $\mathrm{~ns}^{\mathrm{b}}$ \\
\hline $\mathrm{A} \times \mathrm{P}$ & 1 & 9.92 & 12.41 & 0.003 & $* *$ & 1.06 & 0.92 & 0.35 & ns & 5.34 & 3.04 & 0.10 & ns \\
\hline $\mathrm{A} \times \mathrm{T}$ & 1 & 0.35 & 0.65 & 0.43 & $\mathrm{~ns}$ & 2.23 & 3.18 & 0.09 & ns & 5.75 & 2.22 & 0.16 & ns \\
\hline $\mathrm{P} \times \mathrm{T}$ & 1 & 0.26 & 0.49 & 0.49 & ns & 0.38 & 0.55 & 0.47 & ns & 9.79 & 3.77 & 0.07 & ns \\
\hline$P \times D$ & 1 & 0.61 & 0.47 & 0.50 & ns & 0.03 & 0.02 & 0.89 & ns & 0.85 & 0.56 & 0.46 & $\mathrm{~ns}^{\mathrm{b}}$ \\
\hline $\mathrm{T} \times \mathrm{D}$ & 1 & 0.01 & 0.01 & 0.91 & $\mathrm{~ns}$ & 1.06 & 0.62 & 0.44 & ns & 2.27 & 0.89 & 0.36 & ns \\
\hline$A \times D$ & 1 & 3.19 & 2.47 & 0.14 & ns & 0.38 & 0.31 & 0.59 & ns & 0.08 & 0.05 & 0.82 & $\mathrm{~ns}^{\mathrm{b}}$ \\
\hline $\mathrm{A} \times \mathrm{P} \times \mathrm{T}$ & 1 & 1.66 & 3.14 & 0.095 & $\mathrm{~ns}$ & 3.63 & 5.19 & 0.04 & $*$ & 0.07 & 0.03 & 0.87 & ns \\
\hline $\mathrm{A} \times \mathrm{T} \times \mathrm{D}$ & 1 & 0.54 & 0.60 & 0.45 & $\mathrm{~ns}$ & 0.97 & 0.56 & 0.46 & ns & 0.94 & 0.37 & 0.55 & ns \\
\hline $\mathrm{A} \times \mathrm{D} \times \mathrm{P}$ & 1 & 0.63 & 0.49 & 0.49 & $\mathrm{~ns}$ & 0.04 & 0.03 & 0.86 & ns & 0.15 & 0.10 & 0.76 & $\mathrm{~ns}^{\mathrm{b}}$ \\
\hline $\mathrm{T} \times \mathrm{D} \times \mathrm{P}$ & 1 & 0.34 & 0.37 & 0.55 & ns & 1.06 & 0.62 & 0.44 & ns & 0.94 & 0.37 & 0.55 & ns \\
\hline $\mathrm{A} \times \mathrm{P} \times \mathrm{T} \times \mathrm{D}$ & 1 & 0.72 & 0.79 & 0.39 & ns & 1.16 & 0.68 & 0.42 & ns & 2.56 & 1.01 & 0.33 & ns \\
\hline Plot $(\mathrm{A} \times \mathrm{P})$ & 16 & 0.80 & 0.96 & 0.51 & ns & 1.15 & 1.26 & 0.24 & ns & 1.76 & 1.16 & 0.32 & ns \\
\hline $\mathrm{T} \times$ Plot $(\mathrm{A} \times \mathrm{P})$ & 16 & 0.53 & 0.63 & 0.85 & ns & 0.70 & 0.77 & 0.72 & ns & 2.59 & 1.71 & 0.06 & ns \\
\hline $\mathrm{D} \times$ Plot $(\mathrm{A} \times \mathrm{P})$ & 16 & 1.29 & 1.55 & 0.10 & ns & 1.24 & 1.36 & 0.18 & ns & 1.61 & 1.06 & 0.41 & ns \\
\hline $\mathrm{D} \times \mathrm{T} \times \operatorname{Plot}(\mathrm{A} \times \mathrm{P})$ & 16 & 0.91 & 1.09 & 0.38 & $\mathrm{~ns}$ & 1.72 & 1.88 & 0.04 & $*$ & 2.55 & 1.68 & 0.07 & ns \\
\hline Residual & 80 & 0.83 & & & & 0.91 & & & & 1.52 & & & \\
\hline
\end{tabular}

\footnotetext{
${ }^{\mathrm{a}}$ Factors: + / - algae (A); + / - predation (P); time (T); depth (D); all fixed factors. Plots are random, nested on $\mathrm{A} \times \mathrm{P}$; Plot.

${ }^{\mathrm{b}}$ Residual and $\mathrm{D} \times$ plot $(\mathrm{A} \times \mathrm{P}) \mathrm{MS}$ terms were pooled and the resultant term used as the denominator for the $F$ ratio. Post-hoc pooling was done at $P>0.25$. ${ }^{*} P<0.05$; $* * P<0.01$; $* * * P<0.001$; ns not significant.
} 


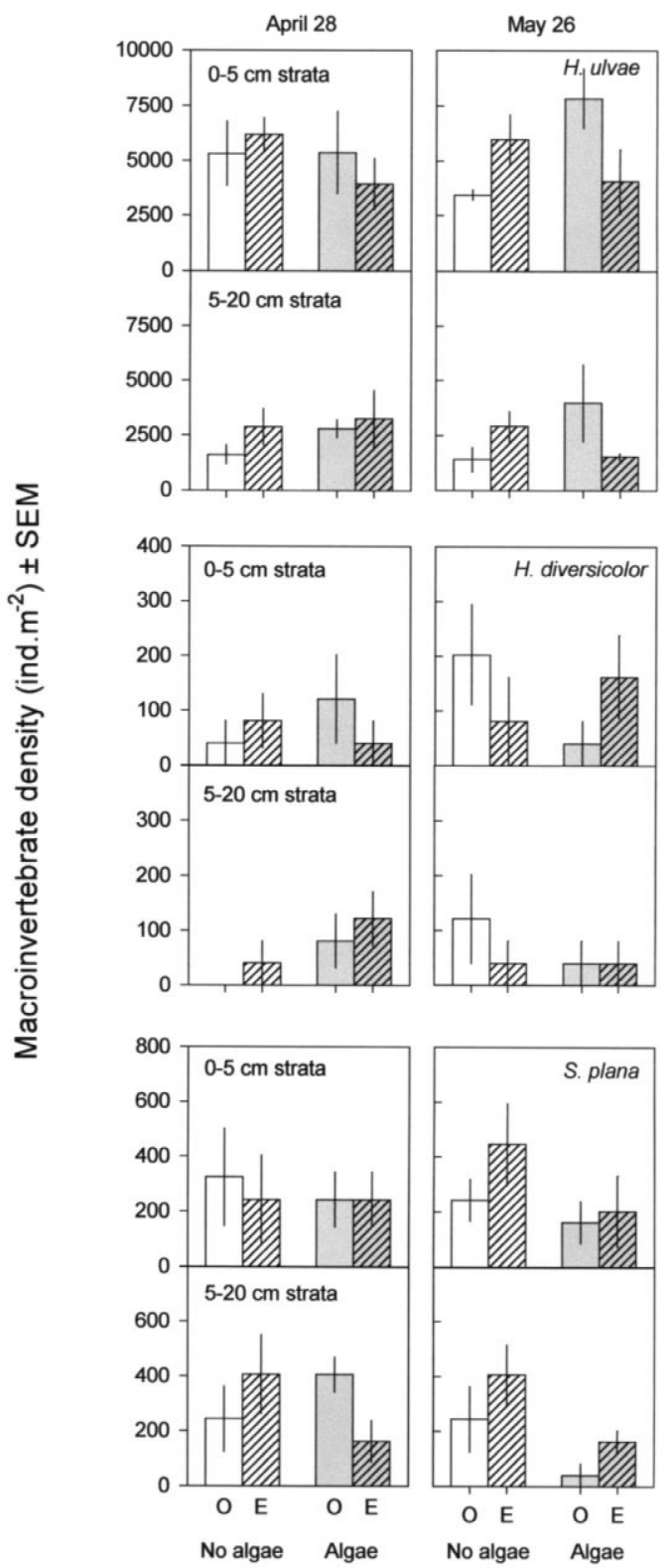

Fig. 3. Macroinvertebrate density in the different depth strata (0-5 and 5-20 cm depth), after 1 (April 28) and 2 months (May 26) after the beginning of the experiment (see Section 2 for description of data). 

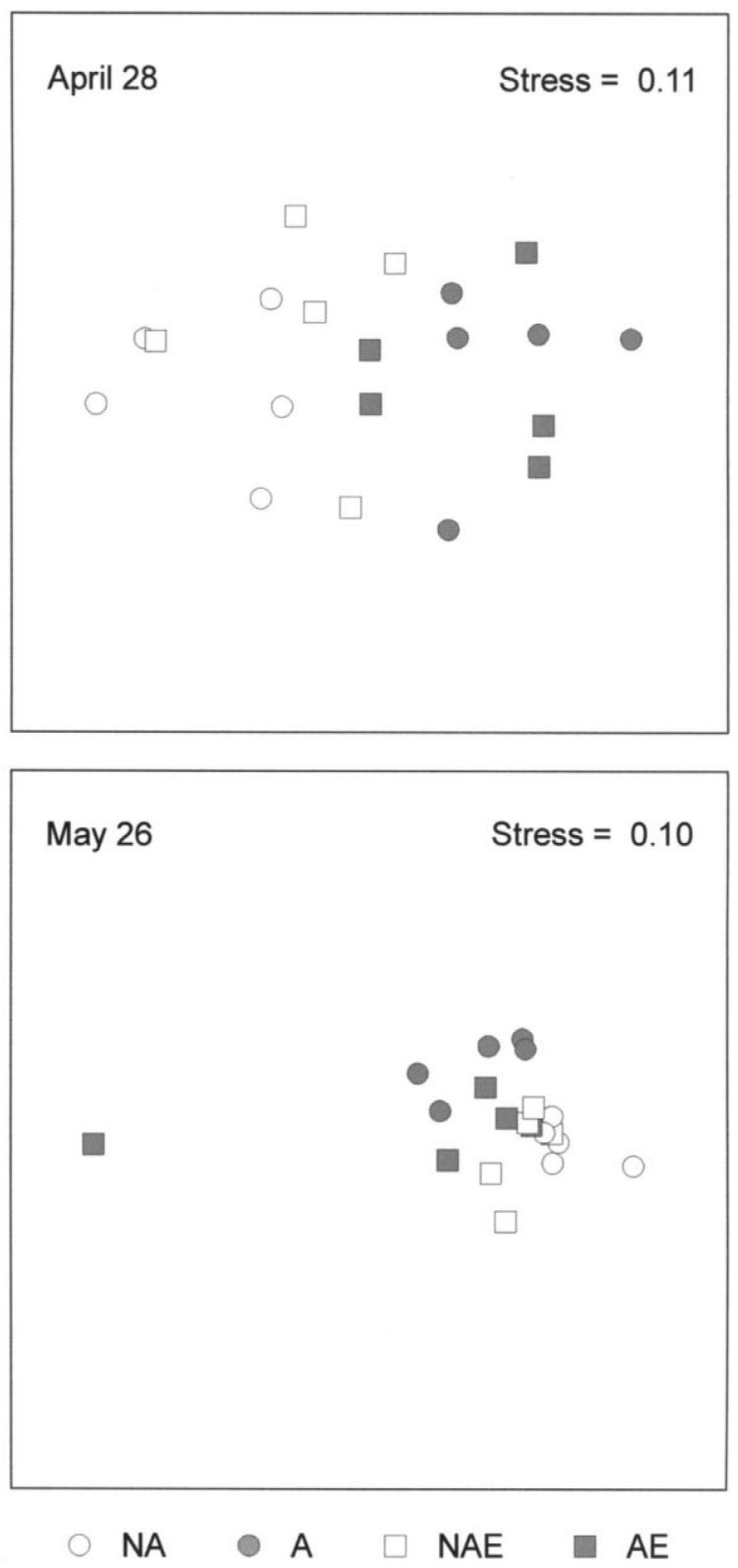

Fig. 4. Two-dimensional MDS ordinations of macroinvertebrates assemblages, averaged for the five cores in each plot after 1 (April 28) and 2 months (May 26) after the beginning of the experiment. NA, open areas with no algal cover; A, open areas with algal cover added artificially; NAE, areas with no algal cover, plus wader exclosures; AE, areas with added macroalgae cover, plus wader exclosures. 
between plots A and NA in each month (Fig. 4). The assemblage of plots NAE did not remain distinct from AE plots, illustrating the outcome of ANOSIM tests.

\section{Discussion}

The effects of macroalgae on macroinvertebrates can be very complex and intense, as reviewed by Raffaelli et al. (1998). These effects can either be direct, due to physical interference with macroinvertebrate feeding behaviour (Hull, 1987; Raffaelli et al., 1991), or indirect, due to changes in physico-chemical characteristics of the sediment (Hull, 1987).

In our study, the presence of macroalgae had a greater impact than predation, not only in magnitude but also in the number of species affected. Macroalgae affected polychaete species, such as the deposit feeder Capitella capitata, the density of which increased significantly where there were algae. This opportunistic species, which usually benefits from organic enrichment (Tsutsumi, 1987, 1990; McLusky, 1989), is more resistant to anoxia than are other deposit-feeders. In other experiments with artificial cover of macroalgae (Hull, 1987; Everett, 1994) and in experiments involving organic enrichment (Raffaelli et al., 1998), similar results have been obtained. The densities of the two other deposit feeders we observed, Amage adspersa and Streblospio shrubsolii, were reduced significantly with macroalgal cover, most likely because they are less resistant to anoxia than are Capitella capitata. They may, however, also be affected because they feed as surface scrapers, a method that may be affected by the presence of algae. In Langstone Harbour, UK, this model was used to explain why the abundance of Streblospio shrubsolii under macroalgal mats was significantly less than in unaffected areas (Soulsby et al., 1982). During the first month of the present experiments, the density of Hediste diversicolor increased significantly with macroalgal cover. The same was observed by Hull (1987). On the second month of our experiment, there was, however, a significant negative effect of macroalgae on density of $H$. diversicolor, possibly due to the increased intraspecific competition for space or food (Wilson, 1989). In the analysis of depth strata, none of the species showed significant alterations in association with macroalgal presence or due to predation. These factors seem to have little effect on stratification.

According to Raffaelli et al. (1998), most large bivalves, because they feed in the water-sediment interface, should have smaller densities under macroalgal cover. In our experiment, the bivalve Scrobicularia plana was not affected significantly. Only Hull (1987) has detected an increase in density of some bivalves, but it was mainly due to the recruitment of new individuals. In our experiment, oligochaetes density did not change numbers, as also found for other oligochaete species in Scotland (Hull, 1987). Everett (1994) noticed an increase in the abundance of oligochaetes in more than one experiment. The most abundant species, the gastropod Hydrobia ulvae, is one species that usually benefits from the presence of macroalgae (Raffaelli et al., 1998), but it was not affected significantly by the macroalgal cover nor by predation. 
Multivariate analysis showed also a clear distinction in community pattern associated with the presence of macroalgal cover, suggesting also that the effect of predation was very weak and did not affect the structure of the community.

\subsection{The effect of exclosure structures}

The maintenance of this type of experiment during a significant period of time can produce some complications: (1) any artefact due to the structures affecting composition of sediments and densities of macroinvertebrates can accumulate during the experiment (algal deposition on the corners of the structures can modify composition of sediment on a continuous way (Sewell, 1996)); and (2) sequential sampling is required to analyse temporal effects on variables such as recruitment, mortality and migration of animals that can be affected by the structures. Wilson (1989) found that, inside cages excluding predators, the greater density of adult Corophium volutator (Pallas) was associated with reduced juvenile density.

The structures were effective excluding waders. Other predators, like fishes and crabs (Carcinus maenas (L.)) were detected several times and, in theory, we can assume that predation by other animals was not affected by the structures.

\subsection{The interpretation of non-significant results}

The interpretation of non-significant results is always difficult. They can be due to the non-existence of real effects or to the inability of the experiment to detect the effects (Underwood, 1997). According to Sewell (1996), even when there are real effects of predation, there is always a problem with the scale of observation. The scale of sampling (usually small cores) may be inadequate because waders feed at a larger scale with a single bird foraging along each path. So, unless a flock of waders systematically foraged in a given area in a regular way, a reduction in density of prey may not be visible at the scale of the experiment. Several studies have failed to detect significant reductions when predators are excluded (e.g., Kalejta, 1993) even though there was evidence of a large intake of prey by a large number of waders (e.g., Kalejta, 1992).

The large spatial variability typical of benthic communities contributes to the low power of most of the experiments. In our experiment, this variability was considered and included in the univariate analysis. Despite the number of replicates (five) the power of the experiment may have been, most of the time, too small to reject the null hypothesis. Since the power is dependent on the magnitude of the average differences relatively to the sampling variability, it is possible that in our experiment this variability was large for some species. To increase the power, say to $80 \%$, it would be necessary to use a number of plots logistically difficult to process.

The effect of some other experimental conditions can make results less clear. Alterations in deposition of sediment, abnormal behaviour of predators or even random movement of the macroinvertebrates (Hall et al., 1990) can lead to non-significant results, even when there are large differences. One very important phenomenon that can 
attenuate the effect of a factor in an exclosure study, is the migration of animals from plots with large densities to areas of smaller density (Hall et al., 1990). The effect of macroalgal cover on the recruitment of invertebrates can also complicate an analysis of the effects under study. If algal biomass is not very large, increased larval deposition can occur (Raffaelli et al., 1998). Where there is a large algal biomass, great mortality of larvae is normal due to the hostile chemical environment (e.g., anoxia in the sedimentwater interface during the night).

So, caution is advised in interpreting results when there is evidence of recruitment or great mobility of individuals during the experiment. However, if this care is taken into account, with prior knowledge for the species in concern, this kind of experiment can be very useful to understand how predation and macroalgae blooms can affect macroinvertebrates. For example, the present study demonstrated that macroalgal cover can, over periods of 1-2 months, control the density of several macroinvertebrates, even at small macroalgae biomasses.

\section{Acknowledgements}

We would like to thank Dr. A.M. Santos for help with statistical analysis and we also thank Professor P.R. Evans and two anonymous reviewers for critical comments on the article. This paper was supported by Portuguese Foundation for Science and Technology through a grant BM/7232/95. [AU]

\section{References}

Aubert, M., 1990. Mediation of microbiological origin and eutrophication phenomena. Mar. Pollut. Bull. 21, 24-29.

Baird, D., Evans, P.R., Milne, H., Pienkowski, M.W., 1985. Utilization by shorebirds of benthic invertebrates production in intertidal areas. Oceanogr. Mar. Biol. Annu. Rev. 23, 573-597.

1983. The birds of the western palearctic. In: Cramp, S., Simmons, K. (Eds.), Waders to Gulls, Vol. III, Oxford University Press, London.

Everett, R.A., 1991. Intertidal distribution of infauna in a central California lagoon: the role of seasonal blooms of macroalgae. J. Exp. Mar. Biol. Ecol. 150, 223-247.

Everett, R.A., 1994. Macroalgae in marine soft-sediment communities: effects on benthic faunal assemblages. J. Exp. Mar. Biol. Ecol. 175, 253-274.

Flindt, M.R., Kamp-Nielsen, L., Marques, J.C., Pardal, M.A., Bocci, M., Bendoricchio, G., Salomonsen, J., Nielsen, S.N., Jorgensen, S.E., 1997. Description of the three shallow estuaries: Mondego river (Portugal), Roskilde Fjord (Denmark) and the Lagoon of Venice (Italy). Ecol. Model. 102, 17-31.

Hall, S.J., Rafaelli, D., Turrel, W.R., 1990. Predator-caging experiments in marine systems: a reexamination of their value. Am. Nat. 136, 657-672.

Hardy, F.G., Evans, S.M., Tremayne, M.A., 1993. Long-term changes in the marine macroalgae of three polluted estuaries in north-east england. J. Exp. Mar. Biol. Ecol. 172, 81-92.

Hodgkin, E.P., Hamilton, B.H., 1993. Fertilizers and eutrophication in southwestern Australia: Setting the scene. Fertil. Res. 36, 95-103.

Hull, S.C., 1987. Macroalgal mats and species abundance: a field experiment. Estuar. Coast. Shelf. Sci. 25, $519-532$. 
Hurlbert, S.H., 1984. Pseudoreplication and the design of ecological experiments. Ecol. Monogr. 54 (2), $187-211$.

Jeffrey, D.W., 1993. Sources of nitrogen for nuisance macroalgal growths in Dublin Bay, Republic of Ireland. Phycologist 34, 30.

Kalejta, B., 1992. Time budgets and predatory impact of waders at the Berg River estuary, South Africa. Ardea 80, 327-342.

Kalejta, B., 1993. Intense predation cannot always be detected experimentally: a case study of shorebird predation on nereid polychaetes in South Africa. Neth. J. Sea. Res. 31 (4), 385-393.

Kalejta, B., Hockey, P.R., 1991. Distribution, abundance and productivity of benthic invertebrates at the Berg River estuary, South Africa. Estuar. Coast. Shelf. Sci. 33, 175-191.

Lillebø, A.I., Pardal, M.A., Marques, J.C., 1999. Population structure, dynamics and production of Hydrobia ulvae (Pennant) (Mollusca: Prosobranchia) along an eutrophication gradient in the Mondego estuary (Portugal). Acta Oecol. 20, 289-304.

Marques, J.C., Rodrigues, L.B., Nogueira, A.J.A., 1993. Intertidal macrobenthic communities structure in the Mondego estuary (Western Portugal): Reference situation. Vie Milieu 43 (2-3), 177-187.

Marques, J.C., Pardal, M.A., Nielsen, S.N., Jørgensen, S.E., 1997. Analysis of the properties of exergy and biodiversity along an estuarine gradient of eutrophication. Ecol. Model. 102, 155-167.

Martins, I., Marques, J.C., Jørgensen, S.E., Nielsen, S.N., 1997. Modelling the effects of green macroalgae blooms on the population dynamics of Cyathura carinata (Crustacea: Isopoda) in a eutrophied estuary. Ecol. Model. 102, 33-53.

McComb, A.J., Humphries, R., 1992. Loss of nutrients from catchments and their ecological impacts in the Peel-Harvey estuarine system, Western Australia. Estuaries 15, 529-537.

McComb, A.J., Davis, J.A., 1993. Eutrophic waters of southwestern Australia. Fertil. Res. 36, 105.

McLusky, D.S., 1989. In: The Estuarine Ecosystem, 2nd Edition, Chapman \& Hall, New York.

Metzmacher, K., Reise, K., 1994. Experimental effects of tidal flat epistructures on foraging birds in the Wadden Sea. Ophelia 6, 217-225.

Múrias, T., Cabral, J.A., Marques, J.C., Goss-Custard, J.D., 1996. Short-term effects of intertidal macroalgal blooms on the macrohabitat selection and feeding behaviour of wading birds in the Mondego estuary (west Portugal). Estuar. Coast. Shelf. Sci. 43, 677-688.

Múrias, T., Cabral, J.A., Lopes, R.J., Marques, J.C., 1997. Low-water use of the Mondego estuary (West Portugal) by waders (Charadrii). Ardeola 44 (1), 79-91.

Pardal, M.A., 1998. Impacto da eutrofização nas comunidade macrobentónicas do braço sul do estuário do Mondego (Portugal). PhD Thesis. Universidade de Coimbra.

Piersma, T., 1987. Production by intertidal benthic animals and limits to their predation by shorebirds: a heuristic model. Mar. Ecol. Prog. Ser. 38, 187-196.

Raffaelli, D., 1992. Conservation of Scottish estuaries. Proc. R. Soc. Edinburgh 100B, 55-76.

Raffaelli, D., Hawkins, S., 1996. In: Intertidal Ecology, Chapman \& Hall, London.

Rafaelli, D., Milne, H., 1987. An experimental investigation of the effects of shorebird and flatfish predation on estuarine invertebrates. Estuar. Coast. Shelf. Sci. 24, 1-13.

Raffaelli, D., Raven, J., Poole, L., 1998. Ecological impact of green macroalgal blooms. Oceanogr. Mar. Biol. Ann. Rev. 36, 97-125.

Raffaelli, D., Limia, J., Hull, S., Pont, S., 1991. Interactions between the amphipod Corophium volutator and macroalgal mats on estuarine mudflats. J. Mar. Biol. Assoc. UK 71, 899-908.

Reise, K., Siebert, I., 1994. Mass occurrence of green algae in the German Wadden Sea. Germ. J. Hydrog. (Suppl.) 1, 171-180.

Sewell, M.A., 1996. Detection of the impact of predation by migratory shorebirds: an experimental test in the Fraser River estuary, British Columbia (Canada). Mar. Ecol. Prog. Ser. 144, 23-40.

Soulsby, P.G., Lowthian, D., Houston, M., 1982. Effects of macroalgal mats on the ecology of intertidal mudflats. Mar. Pollut. Bull. 13, 162-166.

Székely, T., Bamberger, Z., 1992. Predation of waders (Charadrii) on prey populations: an exclosure experiment. J. Anim. Ecol. 61, 447-456.

Trush, S.F., Pridmore, R.D., Hewitt, J.E., Cummings, V.J., 1994. The importance of predators on a sandflat: interplay between seasonal changes in prey densities and predator effects. Mar. Ecol. Prog. Ser. 107, 211-222. 
Tsutsumi, H., 1987. Population dynamics of Capitella capitata (Polychaeta; Capitellidae) in an organically polluted cove. Mar. Ecol. Prog. Ser. 36, 139-149.

Tsutsumi, H., 1990. Population persistence of Capitella sp. (Polychaeta; Capitellidae) on a mudflat subject to environmental disturbance by organic enrichment. Mar. Ecol. Prog. Ser. 63, 147-156.

Tubbs, C.R., Tubbs, J.M., 1980. Waders and shelduck feeding distribution in Langstone Harbour, Hampshire. Bird Study 27, 239-248.

Underwood, A.J., 1981. Techniques of analysis of variance in experimental marine biology and ecology. Oceanogr. Mar. Biol. Annu. Rev. 19, 513-605.

Underwood, A.J., 1997. In: Experiments in Ecology: Their Logical Design and Interpretation Using Analysis of Variance, Cambridge University Press, Cambridge.

Wilson, W.H., 1989. Predation and the mediation of intraspecific competition in an infaunal community in the Bay of Fundy. J. Exp. Mar. Biol. Ecol. 132, 221-245. 